\title{
Author Identity and the Struggled for Power in Seratus Hari Keliling Indonesia, Kompas TV
}

\author{
Syahrul Ramadhan and Vani Afrilia \\ Indonesian Language and Literature Department \\ Faculty in Languages and Arts \\ Univeristas Negeri Padang \\ syahrul@fbs.unp.ac.id and vaniafrilia@gmail.com
}

\begin{abstract}
This study is a discourse-based work which analyses the author identity construction in the novel Seratus Hari Keliling Indonesia (Seratus HKI) Kompas TV in order to reveal the authors' struggle for power. The data of this study is obtained from $f$ the vocabulary found in the Seratus HKI Kompas TV. Using the theory of Critical Discourse Analysis (CDA), this study applies the framework model of Norman Fairclough critical discourse analysis with the focus on the textual level. The finding shows that the identity (selfidentification) of the author as a part of the government, local community, and foreigners are very much influenced by the interest of the nation, Indonesian citizens, conservation, environment, humanistic values, nationalism and patriotism. The analysis on the vocabulary found in HKI is emphasized on : (1) the vocabulary as a key words, (2) the usage of pronouns, and (3) rhetorical language's style. Selfidentification on Seratus HKI Kompas TV is relevant with the slogan of Kompas TV inspiring Indonesia by enlighting people and as a documentary journey that insert the national ideology.
\end{abstract}

\section{Keyword: Identity, Power, Seratus Hari Keliling Indonesia, Critical Discourse Analysis}

\section{INTRODUCTION}

The use of language in order to get any various interests on contemporary society (Santoso, 2012: 2) becomes a poin that should not be forgotten. This goes in line with the complexity of society in the information and communication era with various interests that that stand for. These various interests make the author has a potency in inserting any hidden things among the society complexity. It implies on language used by some stakeholders (including the the author). The author has a potency on inserting any interests and actualize those interests. Ultimately, the society becomes an inevitable object on effort of actualize the concerns on using the language. It can be seen from many discources that are published by some media -print, electronic, or online media- unconciously have brought the audience into the target interests. It also can be seen in the finding of Ardianto (2012: 14) that the daily "Harian Pikiran Rakyat" tends to have a negative branding reputation toward the former of Indonesian president, Susilo Bambang Yudhiyono. Meanwhile, "Kompas" tends to have a positive branding reputation for him. The similar outcome comes from Kurniawan and Amaila (2017: 341) related to the support representation by "Jakarta Pos" toward Jokowi as a leader.

The dicourses that are published to society are built based on some factors. This causes of the reality presented to the audience is a reality that has been constructed by author. The process of reality construction closely related with the strategy of constructing reality, applied communication system, internal and external dynamics, whether in the form of ideology, market, sponsorship, and others (Hamad, 2005: 327). It means the author has the capacity and authority of self-identification to be a part of the participants involved. The identity of the author through self-identification becomes a part of one of the participants showing the power that are struggled for. Similarly, Gowhary's finding (2012: 132) about two nominations of Iranian Presidential candidates divided into two opposing parties. Each party uses language to promote the social and politic goal, attract the individual, and become an effective way to grab the power.

Nevertheless, in fact the discourses presented to society cannot be separated with the various interests pinned by the author, including the ideology and any forms of authority.. The author identifies himself to be a part of the interests that they have worked hard. In other words, not only political discourse is close to various forms of power practice, but it is not possible to be found in the discourses of softnews and nuances of entertainment including documentaries, according to Calzati (2015:153) served between serious and relax. Likewise Suryani's finding (2014) that in the fiction documentary film "The Act of Killing" not only shows the reconstruction of the massacre scene of the communist accused from the point of view of the executor, but also shows the reconstruction effort of public perception about PKI and communism of Indonesia which has been imaged as a forbidden organization that incised black note in Indonesian history through massacres on the events of G $30 \mathrm{~S} / \mathrm{PKI}$. Therefore, analysis with critical approaches such as Critical Discourse Analysis (AWK) is needed to explain how this process works.

Documentary became one of the alternative program and got a lot of attention from various national media seen since 2008 until today (2017). It is recorded by Ayawaila (2008: 28) that today's television sets make documentary a foothold for their programs because the tendency of sinetron programs is starting to saturate. This has an impact on the rise of documentary 
programs that can be said to have become a trend of television shows. Relevant to what media do by studying data made by AGB Nielsen Media Research through observation of potential market based on gender, age, social status, economy, lifestyle, and so on (Fachruddin, 2012: 191). The formation of this trend invites the attention of most audiences. Even the implications for the formation of communities of traveling lovers. It is, therefore, interesting to explain how the discourse identity is presented regarding the identification of the discourse self into one of the participants.

Seratus Hari Keliling Indonesia (abbreviated as Seratus HKI or HKI Hundred) performed differently from the travel documentary aired by other national private TV stations. The uniqueness of the program is explained by Bimo Setiawan, Director of Kompas TV (Seratus HKI team, 2015: 6), that the brief, meaningful reviews on the best episodes of Seratus HKI are believed to be more and more Indonesians recognize the wealth and even the troubles or problems experienced by the country. The Seratus HKI Team trip is conducted using public transportation, land routes, rivers, and seas. Do not use private vehicles or commercial aircraft have a chance to see the original face of Indonesia, the actual situation experienced by this country (as discussed in www.luminox.co.id, http://wartakota.tribunnews.com, www.eigeradventure.com, http: //travel.kompas.com, and http://acara.co.id).

This description at least shows the complexity of discourse in the media. This is what allows the analysis of critical discourse to be one approach to explain the identity of discourse in the midst of the power they are strive for. Therefore, the purpose of this study is to explain the identity of the discourse behind the power struggled for Seratus HKI Kompas TV.

\section{METHOD}

This research is a qualitative research that aims to understand the phenomenon experienced by the subject of research holistically through the description on the natural special context by utilizing scientific method (Moleong, 2010: 6). Scientific method is conducted with scientific integrity, that is objective attitude, open, honest, and keep up to scientific truth (Ibnu, et al., 2003: 1). The approach used is a critical approach. It takes an analysis full of criticism, an analysis conveyed to uncover power and hidden ideology as the complexity of human communication in today's industrial society and information (Santoso, 2012: 136). It is relevant to the idea that the social context that exists outside media influences discourse in the media (Eriyanto, 2009: 320) so that reality is comprehended as a reality that is mediated by values (Hidayat, 1999: 32).

The method used is critical discourse analysis method, that is Norman Fairclough analysis framework. The focus point of Fairclough attention sees discourse as a power practice. This research is focused on being textual dimension, formed vocabulary on revealing the identity of the discourse behind the power struggled for Seratus HKI Kompas TV. The sources of the data in this research is a documentary video of Seratus Hari Keliling Indonesia that broadcasted by Kompas TV. The data is a documentary discourse of Seartus HKI Kompas TV's journey in the form of vocabulary that reflects the author's self-identification in certain participants. Data collection method used is documentation. Documentation is a proven process based on any type of sources, whether in writing, oral, drawing, or archeology (Notosusanto, 1983: 38); documentation is a technique of collecting data about things or variables in the form of notes, transcripts, books, newspapers, magazines, inscriptions, minutes of meetings, agenda, and so on (Arikunto, 2006: 231). Researchers acts as instruments (Moleong, 2010: 168) assisted by data collection tool.

As the data had been collected, followed by sorting data in the form of vocabulary which reflects the self-identification of the author in groups of participants on the documentary discourse journey of Seratus HKI program, Kompas TV. The examination of data validity is conducted by carefully reading, checking and intensifying data analysis (Badara, 2012: 74). The technique of data validation used triangulation technique. Triangulation techniques require researchers to check the validity of data by exploiting something else from the outside (Moleong, 2010: 330). Triangulation technique consists of four kinds, those are examination techniques that utilize sources, methods, investigators, and theory (Denzin, in Moleong, 2010: 330). Triangulation of investigator is done by triangulation technique by utilizing the source of investigator, that is the expert judgment outside the researcher who also check the result of the data collecting. Data analysis was conducted by critical discourse analysis of Norman Fairclough model, that is description, interpretation, and explanation phase.

\section{FINDING AND DISCUSSION}

The identity of the discourse author as the form of power that Seratus HKI Kompas TV fought for is the way of author's self-identification in some certain of participant. Seen from the vocabulary used, Seratus HKI Kompas TV identified oneself as government, local society, foreigners (Table. 1) that struggle for the interests of the nation, Indonesian society, conservation, environment, humanistic values, nationalism and patriotism.

TABLE. 1 AUTHOR'S SELF-IDENTIFICATION AS A PARTICIPANT IN THE SERATUS HKI DISCOURSE.

\begin{tabular}{|l|l|l|}
\hline No. & Author's self-identification as & Percentage \\
\hline 1 & Government & $14,17 \%$ \\
\hline 2 & Local society & $78,33 \%$ \\
\hline 3 & Foreigners & $7,5 \%$ \\
\hline
\end{tabular}


Participants who are classified into government are local government, central government, and government authorities over the topics raised. Local communities are people who ar born as indigenous peoples and becomes indonesian citizens. Foreigners are people who are not Indonesian citizens and are not born as Indonesian.

Seratus HKI Kompas TV dominantly takes a self-identification as local society which supports the concerns of the nation, Indonesian society, conservation, environment, humanistic values, nationalism, and patriotism. Self-identification as local society in several specific categories are the form of power struggled for by Seratus HKI. Placing oneself as a part of government, local society, and foreigners to the interests of nations and Indonesian society are being reflected through particular vocabulary used as the form of relationship between language and authority. Titscher (et.al) viewed from perspective of discourse analysis, the production of texts leaves what is called as "clue" in the text, so the process of interpretation is based on textual elements. It also becomes a part of relation among language, power, and identity besides the potential of CDA in offering the answer for the connection of social, language, ideology, politics, and culture (Rahimi and Riasati, 2011). In other words, discourses appeared in public as Hamad (2005: 37) said coming from the process of reality construction related to the strategy in constructing the reality, applied communication system, and internal as well as external dynamics; reality construction is a part of discourser production mechanism which supports the power (Karnanta, 2012:1).

Besides self-identification as local society related to the interests of the nation, the people of Indonesia, Seratus HKI Kompas TV is also identified oneself as government. It is because of the government's sympathy toward Indonesian people. The effort in self-identification as government or on government side - as local government, central government, or government authorities over the topics raised - is a kind of support and appreciation toward what is Seratus HKI Kompas TV have done to the government as the form of power, which defends for the interests of society, Indonesian citizens. The author (in this Seratus HKI, Kompas TV) placed and identified oneself with the problems or related social communities; Which groups want to be identified with? As a part of communities or independently (Eriyanto, 2009: 304).

The consistency of attitude in struggling the interests of society, Indonesian citizens, is not only by identifying itself as government, but also by identifying itself on the foreigners side. Self-identification as foreigners or on the foreigners' side is related to the concerns and the efforts of foreigners to the society, Indonesian citizens, -in education, health, conservation, and environment. Standing in the foreigners' side because of their works for Indonesia is a kind of appreciation, support, and the form of power which is defended for Seratus HKI, Kompas TV. Self-identification as foreigners related to the interests of the society, Indonesian citizens, involved the citizens indirectly through the vocabulary referred to a set of particular categories, the usage of language style, or directly through the use of pronoun we/us which involved the society as a part of the authors. It is parallel with Fairclough's opinion about the elements of persuasion in a documentary discourse that the texts combine the information, persuasion, and entertainment (Titscher, et.al., 2009: 246).

1. Self-identification of Seratus HKI Kompas TV as Government or on the Government Side.

The form of power which is defended by Seratus HKI Kompas TV in the documentary discourse of Seratus HKI reflected the existence of self identification on government side. The self identification as government or on the government side is a form of power and the strengthens of identity through the vocabulary referred to the form of self identification on government's position in several categories (Table 2).

TABLE 2. SELF IDENTIFACTION OF SERATUS HKI KOMPAS TV AS GOVERNMENT

\begin{tabular}{|l|ll|l|}
\hline $\begin{array}{c}\text { Self } \\
\text { Idenfication as }\end{array}$ & \multicolumn{1}{c|}{ Category } & \multicolumn{1}{c|}{$\begin{array}{c}\text { The Use of } \\
\text { Vocabularies }\end{array}$} \\
\hline Government & 1. & $\begin{array}{l}\text { The inisitative in development planning to improve the } \\
\text { economy and welfare of Indonesian society; } \\
\text { conservation and environmental issues; } \\
\text { awareness and initiative to empower regional potential for } \\
\text { the welfare of the community; } \\
\text { 2. }\end{array}$ & $\begin{array}{l}\text { Specific keywords and } \\
\text { pronouns }\end{array}$ \\
& $\begin{array}{l}\text { attitude of nationalism, patriotism for NKRI; } \\
\text { efforts to respond and overcome crucial issues in Papua, in } \\
\text { Eastern Indonesia. }\end{array}$ & \\
\hline
\end{tabular}

Self identification on the government side is a form of position taken by Seratus HKI, Kompas TV, showing the similarity of viewpoint and partisanship to the government. The use of vocabulary as a particular keyword refers to a set of specific categories that show concern, effort, various policies and government actions related to a number of issues concerning the interests of society, the Indonesian nation. Taking self identication on the government side which is struggling for the interests of society, Indonesian citizens, is relevant to the national ideology which is Seratus HKI imagined. Relevant to Heriyadi, (2010: 35) about the existence of language relations and eternalizing power in the political speech of SBY as the Presidential Candidate and Vice President of Indonesia 2009--2014. 
Self-identification of Seratus HKI, Kompas TV as government is the form of power and strengthens the identity. The self-identification is seen through the vocabulary used; the vocabularies refer to the form of self-identification on the government position as an identity of Seratus HKI, Kompas TV. The self-identification of the author is seen through the use of vocabulary in the form of a particular keyword and the use of pronouns. It can be explained as follows:

a. The Use of Vocabulary in the form of Specific Keywords

The power practice in the form of self-identification as the government is reflected through the use of vocabulary in the form of keywords or specific keywords. The use of vocabulary (keywords) refers to a set of specific categories that shows author's point of view related to the problems arise. The self-identification, Seratus HKI, as the government or on the government side through the keywords that directs to the particular point of views showing the partisanship and the agreement of Seratus HKI, as the example as follows:

(1) The government keeps looking for the way how to prevent the spread of HIV widely, as early as possible can be detected and handled by specific policy of PITC, all patients got tested, condom campaign by local government, too expensive drugs, under government guarantee until now (source E13T8).

Example (1) is the self-identification as government which cares to the HIV/AIDS patients and HIV/AIDS' problems in Papua. The self-identification on the government side is seen through the diction represented the efforts and performance of the government when handled the crucial problem, like HIV/AIDS. It can be seen through the diction the government keeps looking for the way how to prevent the spread of HIV, as early as possible can be detected and handled by specific policy of PITC, all patients got tested, condom campaign by local government, too expensive drugs, under government guarantee until now. The concerns and various policies done by government are kinds of the government's responsibilities to protect the citizens. Positive actions shown by government are also one of Seratus HKI's desires till it identified oneself as government or on the government side. It is relevant to Fairclough (2003: 2-3) that it needs whole analysis to see how language user brings the specific ideology because language historically and socially is kind of actions in relations between dialects and social structures.

Self identification on the government side is a form of position taken by Seratus HKI, Kompas TV, showing the similarity of viewpoint and partisanship to the government.The use of vocabulary in the form of a particular keyword refers to a set of specific categories that show concerns, efforts, various policies and government actions related to a number of issues concerning the interests of society, the Indonesian nation. Self-identification on the government side that struggles for the interest of society, Indonesian citizens, is relevent to the national ideology figured out by Seratus HKI. Relevant to Karnanta (2012: 1) about the form of discourser production mechanism (discourse in this case) that reinforces the power in constructing reality on the production of documentary film. There is a relationship between language and the existence of language relations and eternalizing power in the political speech of SBY as the Presidential Candidate and Vice President of Indonesia 2009-2014 (Heriyadi, 2010: 35 ;

\section{b. The Use of Vocabulary (Pronouns)}

Besides the use of vocabulary in the form of keywords that direct to a set of specific categories, the power practice on the discourse of Seratus HKI related to the self-identification on the government side is also reflected through vocabulary in the form of specific pronouns. The use of vocabulary in the form of pronouns is used to identify oneself on the government side related to their concerns and contributions to conservation problem and environment that reflects through the use of pronoun we, us, and me as the example below:

(2) We went along the edge of forest, we decided to take rest for awhile., we started enter the forest, ... and it became our responsibility, ... for me Betung Kerihun today was amazing, the right place to escape from the boisterous city the perfect wild nature (source E1T10, E1T11, E1T12, E1T14).

We refers to the team of Seratus HKI who takes a position as a part of patrol officers who joined in mitigation team of Elephant of Sumatera. The use of pronoun we is a kind of self-identification of Seratus HKI, Kompas TV, as government or on the government side. Seratus HKI, Kompas TV, becomes a part of officers of Betung Kerihun National Park who patrol Betung Kerihun National Park, parts of nature resources of Indonesia, although it is not easy to do. The awareness, the responsibility of the government in protecting the nature are kinds of Seratus HKI struggle for, because it concerns with the interest of nation, Indonesian people. Meanwhile, the use of pronoun we refers to the team of Seratus HKI who positioned itself as a part of government as well as involving audience; $m e$ refers to personal host who strengthen its position as an observer who appreciates government's hard work to protect vegetation in the Betung Kerihun National Park. The use of pronoun is the direct form of author's self-identification as government or on the government side. Self-position of Seratus HKI on the government side related to the conservation issues and environment is kinds of concern toward the nation of Indonesia, relevant to the national ideology which Seratus HKI Kompas TV figured out. 
2. Self-identification as Local Society

The power practice in the discourse of Seratus HKI reflects self-identification as local society in the several categories which support the interests of society, Indonesian people, conservation, environment, humanism values, nationalism, and patriotism (table 3).

TABLE 3. SELF-IDENTIFICATION SERATUS HKI KOMPAS TV AS LOCAL SOCIETY OR ON LOCAL SOCIETY SIDE

\begin{tabular}{|c|c|c|}
\hline Self-identification as & Category & The Use of Vocabularies \\
\hline Local Society & $\begin{array}{l}\text { 1. the issues of development equity and public } \\
\text { welfare; } \\
\text { the attitude of nationalism and patriotism against } \\
\text { the Republic of Indonesia; } \\
\text { 3. positive attitudes also appreciate national heroes, } \\
\text { people who cares, inspirational figures, critical and } \\
\text { creative attitude of the younger generation who do } \\
\text { for others; } \\
\text { 4. an appreciation of the effort to reject gender } \\
\text { discrimination; } \\
\text { 5. the existence of character values and attitudes / } \\
\text { points of view in responding to HIV/AIDS and the } \\
\text { various constraints that must be faced by the } \\
\text { people of Papua; } \\
\text { 6. support for local potential, cultural inheritance, } \\
\text { local wisdom, and empowerment / development of } \\
\text { tourism potential; and } \\
\text { 7. support in fighting for conservation and } \\
\text { environment for the sake of nature conservation. }\end{array}$ & $\begin{array}{l}\text { Specific keywords, pronouns, } \\
\text { rhetorical language style. }\end{array}$ \\
\hline
\end{tabular}

Seratus HKI represents self identification on the interests of the people and the nation of Indonesia that can not be separated from the national ideology which is generally presented with narrative techniques for things that are emphasis and persuasion. Relevant to Gollwitzer's observations (2011: 143) about the narrative techniques that dominate contemporary TV shows. In addition, the identification of Seratus HKI Program, Kompas TV, as one on the local communities side, demonstrates the efforts of Seratus HKI Program to defend the rights of local communities in addition to the appreciation of nationalistic attitudes, noble values, and concern for the Indonesian nation. Showing partiality to the marginalized in the problematic life (Ulinnuha, , Wening and Yahya, 2013: 262). However, documentaries are a combination of information, entertainment, and persuasion. Not much different from what Pederson (2013: 49) observes about how documentary films are transformed. Selfidentification as local society represents through the vocabulary in the form of (1) keywords (2) pronouns that show self-position, the similarity of viewpoints, and the partisanship to the local society.

a. The Use of Vocabulary in the form of Specific Keywords

The power practice on the Seratus HKI discourse reflects the self-identification of Seratus HKI on the local society side through vocabulary in the form of specific keywords that directs to the public's point of view to what the author's belief. The vocabulary in the form of specific keywords shows the agreement and the partisanship of Seratus HKI to the local society. The author's self-identification as local society or on the local society side is reflected through the keywords that direct to a set of specific categories related to the concern and the contribution of local society to the public issues, Indonesian citizen, as the example (3) below:

(3) Sixty years after the Independent of Indonesia, citizens still haven't got the electricity yet, PLN still does not come yet althought the price of gas twice more expensive than the price in the city (source E9T2).

On the example (3), Seratus HKI is identified itself as a part of local society of Batu Wingkung. The self-identification of Seratus HKI, Kompas TV, is on the local society side through diction in the form of specific keywords that show encoragement and protest to the development which does not spread properly. The use of vocabulary in the form of specific keywords like sixty years after the Independent of Indonesia, citizens still haven't got electricity yet, PLN still does not come into show various limitations coming from people of Batu Wingkung as well as becomes the indicator of the slow expansion of primary needs such as electricity and gas. Although gas' price is expensive, the people of Batu Wingkung have no choice except still bought it because of the needs, although the price of gas twice more expensive than the price of gas in the city. The ilustrations of limitation 
from the citizens all over Indonesia. The use of vocabulary in the form of specific keywords shows self-identification as people of Batu Wingkung. It is the efforts of Seratus HKI Kompas TV to show empathy and ask the audience to empathize other people.

Strengthening the position or self-identification on the local society actually is a part of the efforts of Seratus HKI to inspire the audience to more concern toward the environment, and the other people. The keywords that show how people who has limitation about the tools and the infrastructure and other issues in the frontier, outside region, even in the outlying areas who still have high of nationalism. On the other hand, showing off the inspirational figures, the citizen of Indonesia who live in humble society but care to others. Showing the agreement, apreciation, and partisanship of Seratus HKI are relevant to the ideology brought by Seratus HKI, nationality. It is relevant to the slogan of Kompas TV "Inspirasi Indonesia".

b. The Use of Vocabulary in the Form of Pronouns

The power practice in the form of self-identification as local society on the Seratus HKI discourse is reflected through the vocabulary in the form of specific pronouns. The self-identification as local society or on the local society side is also seen through the vocabulary in the form of pronoun we, us, you, as the example (4) below:

(4) Struck us ... we continued ... we stopped ... we had to wait (source E2T7).

We refers to the team of Seratus HKI Kompas TV and involves the audience. Through the pronoun we, Seratus HKI Kompas TV identified itself as local society or on the local society side and feel empathy to the issues in the society.

As on the example (4) Seratus HKI Kompas TV shows the inappropriate of tools and infrastructures to go to Lebong Landai village, and motivates the people of Lebong Tandai to behave wisely. Lorry motor express (called Molek) is far from good. Railway made by wood with track's condition and a steep road go by the forest, slope, far from good persuade the audience to feel empathy. Seratus HKI Kompas TV identified itself as part of the local society which has empathy for Lebong Tandai as part of them persuade others to feel the same way. Relevant to Fairlough who said the documentary' texts combined information, persuation, and entertainment (Titscher, S., 2009: 246). Placing or positioning itself as local society means agree and shows the partisan to what local society do. The use of pronouns concretes over and emphasizes how Seratus HKI declared their position.

c. The Use of Vocabulary in the form of Rhetorical Language Style

The power practice in the form of self-identification as local society or on the local society side is reflected through the use of vocabulary in the form rhetorical language style. The use of vocabulary in the form of rhetorical language style emphasizes the author's position as local society or on the local society side. Relevant to the functions of rhetorical language style: to beautify the discourse, emphasize the argument, and to concrete over the discourse (Manaf, 2008: 166). Self-identification on the local society side, emphasize the position of Seratus HKI about their partisanship to local society, as the example (5) below:

(5) Weightlifting and Padepokan Gajah Lampung taught me that there is no instant way to success, instead of the existenceof certain aim, work hard, and the consistent of attitude to reach the goal (source E1T7).

As on the example (5), the team of Seratus HKI identified itself on the local society that is reflected through vocabulary using rhetorical language style in the form of climax, such as instead of the existence of certain aim, work hard, and the consistent of attitude to reach the goal. Positioning itself as local society or on local society side, Padepokan Gajah Lampung is parts of Seratus HKI's efforts to create public's empathy. On the other hand, it also inspires the audience through an inspirational figure, a local hero, who guides athletes to keep working in order to make Indonesian people proud and earn money for the family. It can be seen from weightlifting and Padepokan gajah Lampung taught me that there is no instant way to success.

Self-identification as local society or on the local society side because of their limitations, their belief about the national's values, and caring to others fits to the national ideology brought by Seratus HKI. Placing itself to the local society's position shows the efforts of Seratus HKI struggling the rights of local society besides appreciate the nasionalism, local wisdom, and concerns toward Indonesian people. Inspiring and giving information that encourage empathy and public's critical side are relevant to the slogan of Kompas TV "Inspirasi Indonesia".

\section{Self-identification as Foreigners}

Self-identification on the foreigners side emphasizing the partisanship is the form of self-identification imagined by Seratus HKI and parts of the power practice (table 4). 
Table 4. Self-identification Seratus HKI Kompas TV as Foreigners or on the Foreigner Side

\begin{tabular}{|l|l|l|l|}
\hline $\begin{array}{c}\text { Self- } \\
\text { identification } \\
\text { as }\end{array}$ & \multicolumn{1}{|c|}{ Category } & The Use of Vocabularies \\
\hline Foreigners & $1 . \begin{array}{l}\text { conservation, environment, and endemic conservation in } \\
\text { Indonesia; }\end{array}$ & $\begin{array}{l}\text { Specific Keywords, and } \\
\text { Rhetorical } \\
\text { Language } \\
\text { Indonesia, improving people's welfare, and handling various } \\
\text { humanitarian problems; } \\
\text { contribution in the development of tourism potential and } \\
\text { nature of Indonesia. }\end{array}$ & \\
\hline
\end{tabular}

Self-identification as foreigners is reflected from the use of vocabulary through the form of symbolic power. The symbolic power is an interpretation involving awards and prestige that will control and handle the audience (in this case) in order to accept the inserted message (Santoso, 2012: 8). Self-identification as foreigners or on the foreigners side is seen through the use of keywords that refer to a set of specific categories which represents the partisanship and the utilizing rhetorical vocabulary. It can be explained one by one as follows:

a. The Use of Vocabulary in the Form of Specific Keywords

The power practice related to the author's self-identification is reflected through the use of vocabulary in the form of specific keywords that direct to the viewpoint of a set of category wanted by author. Self identification on the side of foreigners is a form of appreciation for the concern and contribution of foreigners to Indonesia although was not be born as Indonesian, as the example (6) below:

(6) Figures of Tjong A. Fie is very commendable for the development, ... obvious proofs from Tjong A. Fie who built this city, highly regarded figures, no 1 figures related to the tollerant of religion in Medan, a humanitarian who donors most of the place of worships, ... Not the native of Bali, contributed moved her to change, American lady lives in Bali for years, take a big part in improving the quality of mothers-to-be, the amazing contribution to people of Ubud Bali (E4T17, E17T1).

As on the example (6) Seratus HKI Kompas TV identified oneself as foreigners or on the foreigners side, Tjong A. Fie and Robin Lim who both of them are foreigners, but contributed and did for Indonesian people. The use of vocabulary in the form of specific keywords as in the example (6) shows the facts that the foreigners show the concern more than average to Indonesia. It is a part of Seratus HKI Kompas TV's efforts to inspire the audience, Indonesian citizens, in order to be persuaded and do something to their own nation. Relevant to the documentary discourse as the combination of information, persuation, and entertainment (Titscher, 2009: 246). Author's self-identification as foreigners shows the support and author's apreciation toward the concern of the foreigners to the nation relevant to the national ideology brought by Seratus HKI. It is relevant to the slogan of Kompas TV "Inspirasi Indonesia”.

b. The Use of Vocabulary (Language Style) Rhetorical

Self-identification on the foreigners side who are not Indonesian citizen places the appreciation of Seratus HKI of their concerns and contribution to the Indonesia, as the example (7) as follows:

(7) No need to be born in the Motherland to become a true Indonesia because loving this country can be done by doing small things, but giving a meaningful change (source E4T4).

In example (7) is one of the examples of utilizing the vocabulary with rhetorical language style that directs to the effort of achieving the specific meaning, that is encourage public's self-awareness to empathize. It is relevant to the function of rhetorical language style refining a discourse to be more concrete, smoother, more polite, and emphasize the argument.

Self identification on the foreigners side gives a particular effects to the audience. Not only appreciate the foreigners, but also inspire local society to be more concerned and emulate foreign contributions. Concretize and reaffirm the contribution of foreigners, giving space to the audience to be inspired through the use of soft vocabulary, polite, and utilize the rhetorical language style. It is relevant to the national ideology and the slogan of Kompas TV "Inspirasi Indonesia".

\section{CONCLUSION}

The identity (self-identification) of the author as a person behalf to the government, local community, and and foreigners in some categories which concern with the interest of the nation, Indonesian citizen, conservation, environment, humanistic values, nationalism and patriotism as a form of power Seratus HKI is realized through: (1) the vocabulary as a key words, (2) the usage of pronouns, and (3) rhetorical language's style. The discourse genre of Seratus HKI Kompas TV as a journey documentary discourse that inserted the national ideology, so that their self-identification to the community or a particular participant is also 
relevant to Kompas TV as an enlighting people media or relevant to its slogan "Inspirasi Indonesia". Conveying the knowledge and experiences during the journey around Indonesia by inserting the power practice to fight for the rights of certain people about their own interests, the interests of nation so that the people empathize, proud of the wealth of Indonesia, the complexity, the diversity, therefore they are being inspired to work, to act, and to care about their own nation. Educate the audience to see Indonesia positively, to understand the limitations and to do better for the interests of the nation relevant to the elements of persuasion as other documentary genres and also related to crucial issues in Indonesia, especially socio-cultural issues from January to March.

The following suggestions may be considered related to this research. First, as the audience is supposed to be the critical attitude of mebina in addition to being open minded is one of the alternatives in order not to enter into a set of categories that can be divisive Union Nations especially. Second, as a journalist, editor, or media in order to foster an atmosphere of professional berlandas work on the code of ethics of journalism looks like it could be a wise alternative. Third, as educators, provide awareness and familiarise the students think critically is a competence that can be trained so that they are not easily being herded in the interests of the person. Fourth, as Indonesia language students especially have an interest in the study of critical languages, can apply the theory of critical discourse analysis of some models to enrich the discourse analysis of related findings.

\section{References}

Acara.co.id. (2015). Seratus Hari Artis Jelajah Pelosok Indonesia”. Retrieved August 23, 2015, from http://acara.co.id/100-hariartis-jelajah-pelosok-indonesia/.

Ardianto, E. (2012). Analisis wacana kritis pemberitaan harian pikiran rakyat dan harian Kompas sebagai public relations politik dalam membentuk branding reputation Presiden Susilo Bambang Yudhoyono (SBY)”. Ilmu Komunikasi, 2 (1), April $2012,14-57$.

Arikunto, S. (1997). Prosedur Penelitian Suatu Pendekatan Praktik. Jakarta: Rineka Cipta.

Ayawaila, G. R. (2008). Dokumenter dari Ide sampai Produksi. Jakarta: FFTV-IKJ Press.

Badara, A. (2012). Analisis Wacana: Teori, Metode, dan Penerapannya pada Wacana Media. Jakarta: Kencana.

Calzati, S. (2015). Travel writing on the edge: an intermedial approach to travel books and travel blogs. Sapientiae, Film and Media Studies, Oktober 2015, pp: 153--168.

Eigeradvanture. (2013). Eiger Menemani Seratus Hari Keliling Indonesia. Retrieved August 23, 2015, from http://www.eigeradventure.com/content/eiger-menemani-100-hari-keliling-indonesia-\%E2\%80\%93-Kompas-tv.

Eriyanto. (2009). Analisis Wacana: Pengantar Analisis Teks Media. Yogyakarta: LKIS.

Yuliarni. 2013. Pro dan Kontra dalam Pemberitaan RUU Antipornografi dan Pornoaksi dalam Artikel Majalah Al-Waei. Parole, $3(1), 9-20$.

Fachruddin. (2012). Dasar-dasar Produksi Televisi: Produksi Berita, Feature, Laporan Investigasi, Dokumenter, dan Teknik Editing. Jakarta: Prenada Media Group.

Fairclough, N. (2003). Language Power: Relasi Bahasa, Kekuasaan dan Ideologi. In Indah Rohmani (Eds). Malang: Boyan.

Fairclough, N. (2004). Analysis Discourse: Textual Analysis for Social Research. USA dan Canada: Taylor dan Francis eLibrary.

Gollowitzer, D. (2011). How to rule a tv show? Narration in 24. Sapientiae, Film and Media Studies, April 2011, $143--156$.

Gowhary. (2014). A critical discourse analysis of the electoral talks of Iranian presidential candidates in 2013. Second global conference on lingistics and Foreign Language Teaching, Procedia-Social and Behavioral Sciences, 192, $132-141$.

Hamad, I. (2005). Lebih dekat dengan analisis wacana. Mediator, 8 (2), December 2007, 325-343.

Heryadi, T. Analisis Wacana pidato politik Susilo Bambang Yudhoyono sebagai calon presiden Republik Indonesia 2009 -2014. Administratur, 3 (2), August 2010, 35--54.

Ibnu, S. (2003). Dasar-dasar Metodologi Penelitian. Surabaya: Universitas Negeri Malang dan Lembaga Penelitian Universitas Negeri Malang.

Karnanta, K. Y. (2012). Ekonomi politik film dokumenter Indonesia dependensi industri film dokumenter Indonesia kepada lembaga donor asing. Lakon, 1(1), Juli 2012, 1--20.

Kompasiana. (2011). Kompas TV Inspirasi Indonesia. Retrieved August $23,2015 \quad$ from http://www.Kompasiana.com/ar mutajalli/Kompas-tv-inspirasiindonesia 550a34a9a3331133712e392a.

Kurniawan E. dan Amalia D. U. (2017). The representation of Joko Widodo's figure in the Jakarta Post. Indonesian Journal of Applied Linguistics, 6 (2), January 2017, 341-350.

Luminox. (2013). Seratus Hari Keliling Indonesia. Retrieved August 23, 2015 from http://www.luminox.co.id/100-hari-kelilingindonesia/.

Manaf, N.A. (2008). Semantik Teori dan Terapan dalam Bahasa Indonesia. Padang : Sukabina Offset.

Mast, G. and Bruce F. K. (2010). A Short History of the Movie. Los Angeles: Pearson.

Moleong, L.J. (2010). Metode Penelitian Kualitatif. Bandung: Remaja Rosda Karya. 
Mylonas, Y. (2007). Crisis, conspiracy and rights: imaginaries of terrorism in documentary film". Critical Approaches to Discourse Analysis across Disciplines, 2 (2), 2006, 96--117.

Pedersen, P.O. (2013). The never-ending disaster: 9/11 conspiracy theory and the integration of activist documentary on video websites. Sapientiae, Film and Media Studies, June 2011, 49--64.

Rahimi, F. and Mohammad J. R. (2011). Critical discourse analysis: scrutinizing ideologically-driven discourses. Humanities and Social Science, 1 (16), November 2011, 107--112.

Santoso, A. (2012). Studi Bahasa Kritis: Menguak Bahasa Membongkar Makna. Bandung: Mandar Maju.

Sinetron Indonesia. (2015). Ini Dia Penyebab Sinetron 'Tukang Bubur Naik Haji' Nggak Tamat-tamat. Retrieved January 14, 2015 from http://sinetrron-indonesi.com/ini-dia-penyebab-sinetron-tukang-bubur-naik-haji-ngk-tamat-tamat.

Suryani, A. (2014). The Act of Killing: Rekonstruksi Sejarah Di Balik Rekonstruksi Adegan (Suatu Analisis Wacana Kritis). Unpublished master's thesis. Universitas Esa Unggul.

Tim Seratus Hari Keliling Indonesia Kompas TV. (2015). Seratus Hari Keliling Keliling Indonesia. Jakarta: Bhuana Ilmu Populer Kelompok Gramedia.

Titscher, S. (2009). Metode Analisis Teks dan Media. Yogyakarta: Pustaka Pelajar.

Travel Kompas. (2013). Pagi ini Perjalanan 100 Hari Keliling Indonesia Kompas TV pun Dimulai. Retrieved August 23,2015 from http://travel.Kompas.com/read/2013/01/13/10285645/Pagi.Ini.Perjalanan.100. Hari.Keliling.Indonesia.Pun.Dimulai.

Ulinnuha R., Wening U. and Yahya W. (2013). Critical discourse analysis: theory and method in social and literatury framework. Indonesian Journal of Applied Linguistics, 2 (2), January 2013, 262-274.

Wartakota. (2013). Kompas TV Gelar Seratus Hari Keliling Indonesia. Retrieved August 23, 2015 from http://wartakota.tribunnews.com/2013/01/07/Kompas-tv-gelar-100-hari-keliling-indonesia.

Yuliarni. 2013. Pro dan Kontra dalam Pemberitaan RUU Antipornografi dan Pornoaksi dalam Artikel Majalah Al-Waei. Parole, $3(1), 9-20$. 